\title{
Cognitive functioning of monolingual and bilingual adolescents: attention, semantic memory and self-efficacy
}

Funkcjonowanie poznawcze młodzieży dwujęzycznej i jednojęzycznej: uwaga, pamięć semantyczna, poczucie kompetencji osobistej

\author{
Alicja FREDO ${ }^{1}$ \\ Uniwersytet Gdański \\ Henryk OLSZEWSKI ${ }^{2}$ \\ Uniwersytet Gdański
}

\begin{abstract}
This paper aims to discuss the impact of being monolingual or bilingual on cognitive functioning of an individual as well as its influence on their self-efficacy. The literature review points to certain trends in adults' functioning; however, the study based on young adults and adolescents still displays avenues for elaborating on new correlations. There is a proven relation between cognitive processes and bilingualism; however, their relation to self-efficacy is still to be determined. In the study, adolescents were examined by means of three psychological tools focusing on attention span, verbal fluency and self-efficacy. In spite of the fact that major correlations appeared relatively similar, we observed certain correlations within some of the variables after conducting an in depth analysis of the results in the respective section.
\end{abstract}

Keywords: bilingualism, adolescence, attention, semantic memory, self-efficacy, verbal fluency

1 (C) https://orcid.org/0000-0001-6249-805X.

2 (D) https://orcid.org/0000-0002-2573-3425. 


\section{Streszczenie}

Niniejsza praca ma na celu omówienie w jaki sposób bycie jednojęzycznym oraz dwujęzycznym może wpływać na funkcjonowanie poznawcze jednostki oraz jaki wpływ ma to na poczucie własnej skuteczności. Dotychczasowa literatura wskazuje na pewne trendy w zakresie funkcjonowania osób dorosłych, co stwarza przestrzeń dla dalszych badań na tym polu. W niniejszym badaniu nastolatkowie zostali przebadani trzema narzędziami psychologicznymi w celu zbadania poziomu koncentracji uwagi, fluencji słownej oraz poczucia własnej skuteczności. Nie zaobserwowano znaczących korelacji pomiędzy zmiennymi; zaobserwowano natomiast korelacje, które mogą wskazywać na określone tendencje potwierdzające dotychczasowe doniesienia $\mathrm{w}$ literaturze. W celu przeanalizowania otrzymanych wyników przedstawiono ich dyskusję wraz z wnioskami oraz ze wskazaniami do przyszłych badań.

Słowa kluczowe: dwujęzyczność, dorastanie, uwaga, pamięć semantyczna, poczucie kompetencji osobistej, fluencja słowna

\section{Introduction}

Nowadays, bilingualism remains of much greater interest to scientists than it used to be. Numerous scientific publications in this field have significantly contributed to the development of studies on bilingualism and foreign languages acquisition regarding communication skills. Focusing psycholinguistics' interest on this notion has created a structured research material that presents itself in numerous textbooks, scientific journals, or topicrelated conferences. It is estimated that up to two-thirds of children in the world are raised in the bilingual environment (Crystal, 1997). Crystal points to data which suggests that more than 570 million people speak English worldwide, and for forty-one percent of them belong to a second language (1997). Also, it is assumed that a number of bilinguals is expected to keep increasing due to globalization processes.

The modern research references state the relationship between the state of being bilingual and the functioning of attention and memory. Still, the relationship between these factors and perceived self-efficacy seems to pose a scientific interest. The results of the research will enable to illustrate existence or lack of connection between selected factors, which, in turn, will allow drawing general conclusions regarding the time of shaping selected aspects of cognitive functioning and self-efficacy. The critical literature review indicates some trends regarding the functioning the adults, which creates space for further research in this field. 
Approaches to the definition of a bilingual person have been a focus of multiple theories. The study of bilingualism covers a considerably wide range of aspects concerning both the individual characteristics of given languages users as well as the broad, social and cultural factors conditioning the use of these languages in a given society (Bhatia, 2006). Edwards (2004) claims that anyone who understands at least one expression in a foreign language can consider themselves a bilingual person. Other approaches suggest that only people who speak a language as advanced as their first language can claim to be bilinguals. Myers-Scotton (2013), on contrary, rightly notes that this approach would effectively narrow down the number of people who could consider themselves bilingual.

The investigation proves that bilingualism is determined by cognitive processes, classification of which may be based on the conscious control criterion (Schneider and Shiffrin, 1977). From a theoretical viewpoint, automatic processes are basically subconscious, being unaware of involving lesser resources of attention (Posner, Snyder, 1975). Another view emphasises that controlled and automatic processes are established on a continuum, from controlled to automated processes. It is worth mentioning that the activities managed by controlled processes at some stage get into automated, such as language learned through individual words and phrases, collocations, as well as the literal translation from the first language interpreting into a foreign language. There appears the automation of a translation process, where an emphasis is put not on the speaking process, but on content. An analogous process concerns learning to read, during which an individual focuses on the content instead of ultimate reading. This process is called automation, its duration depending on both a task difficulty and frequency of practicing the given skill (LaBerge, 1975, 1976, 1990).

Language learning involves, among others, semantic memory. Tulving (1972) treats the latter as a part of declarative memory. According to him, semantic memory represents general knowledge, which is verbalized simply and detached from the context. Nęcka (2006) also defines semantic memory as "memory including specific general knowledge, relatively easy to verbalize, detached from the context" (Nęcka, Orzechowski, Szymura, 2006). Semantic memory can be understood as one whose content is the knowledge of symbols, their meaning, and relationships between given symbols. Semantic knowledge is organized at several levels that closely related to a language structure.

Another notion related to bilingualism is verbal fluency that was considered one of the seven constituents of human intelligence (Piskunowicz, 
2013). In later analyses, however, it was pointed out that verbal fluency is comprised of numerous factors: the efficiency of extracting information from long-term memory, operations efficiency, i.e. the attention and cognitive control, access to long-term semantic memory resources, and operational memory (i.e.time monitoring completing a e task). Cognitive control appears of particular importance here, since it poses unconventional situations for an individual. Thus, in case of verbal fluency testing, the task is to generate specific categories of words, which is highly unusual considering the established relationships in declarative memory as well as the differences in the specifics of storing such information in human memory (Nęcka, 2006).

Elaborating on bilingualism in the context of self-efficacy calls for a particular interest, as the latter is considered a key element of human competence. This means that different people with the same skill set will react differently in similar settings, which depends on the fact how an individual perceives their capabilities. An interesting example the Collins (1982) study suggests in which the researcher examines effectiveness of solving mathematical tasks among children. According to the survey, the respondents displayed their performance at three levels. The results proved that, in addition to the impact of mathematical ability on children's performance, a sense of selfefficacy appeared crucial: children who believed in their abilities performed better than those who doubted themselves. It infers that children even with a high degree of skills in a given field may be disturbed precisely because of doubting their skills. (Bandura, Jourden, 1991) Importantly, a positive sense of self-efficacy will make a favourable impact on people's performance regardless of their skills.

\section{Methods}

\subsection{Sample}

The sample consisted of 83 high school students: 72 females (87\%), 11 males (13\%), within the age range between 16 years and 4 months. The focus group included teenagers exclusively. The participants attended the same school, year of study in two different class types: a monolingual class with a basic English course, and a bilingual one with several subjects taught in English alongside with extended hours of advanced English. 


\subsection{Measurements}

The Attention and Perception Scale (TUS; Ciechanowicz, Stańczak, 2006) includes 4773 characters (letters $b$ and $k$ ), some of which are to be crossed out. The letters are placed throughout three A4 pages at random, in 93 rows, each row including from 50 to 52 letters, with at least 12 of them to be crossed out. The task lies in crossing out letters $b$ and $k$ from each row of similar letters. In total, there are 1434 to be crossed out within 3 minutes.

General self-efficacy Scale (GSE; Shwarzer, Jerusalem) has been used in its Polish adaptation by KompOs (Juczyński, 2011). The tool includes two scales, each with six either positive or negative statements. The scale measures self-efficacy components, levels of which reflect how individuals adapt under stressful life conditions as well as cope in everyday life. It is a self-report scale; the responses should be provided first on a scale from "absolutely true" to "completely false", then six statements referring to the mode of conduct frequency.

Verbal fluency scale is based on retrieving and writing down as many words consistent with a chosen criterium within an established time span as possible (max. 60 seconds). The results might reflect the semantic or phonemic fluency. A semantic fluency task was based on retrieving words from a chosen, vast semantic category (here: animals), whereas the phonemic fluency was based on generating words that start with the letter $p$.

Bearing in mind the fact that all of the above mentioned tools are timesensitive, the examination calls for engaging respondents' attention, thus preventing them from being distracted. Ultimately, it would establish possible asymmetries between both groups and enhance the the collected data credibility.

\subsection{Procedure}

The data collection was conducted in 2019 as a paper-pencil study during their school hours. The participants were informed on the aim of the study as well as on their right to remain anonymous and withdraw from the procedure at any point.

\subsection{Statistical analyses}

All the analyses were carried out using IBM SPSS Statistics 23. A number of basic statistical tests were performed. Preliminary assessment was conducted to avoid violations regarding the assumption of normality. The significance 
level was set to $\alpha=0,05$, whereas the statistical tendency level was set at $0,05<p<0,1$.

\section{Results}

Table 1 presents a basic statistical analysis of qualitative variables, that is mean scores, percentages, correlations, and standard deviations.

Table 1. Basic statistical analysis of qualitative variables

\begin{tabular}{lllllllllll}
\hline & $M$ & $M e$ & $S D$ & $S k$. & Kurt. & Min. & Maks. & $K-S$ & $p$ \\
\hline P - points & 12,89 & 13 & 3,64 & $-0,25$ & $-0,07$ & 5 & 21 & 0,15 & 0,004 \\
Animals - points & 15,86 & 17 & 3,92 & $-0,95$ & 0,94 & 4 & 22 & 0,16 & 0,001 \\
Sum & 28,75 & 30 & 6,36 & $-0,55$ & 0,59 & 11 & 41 & 0,12 & 0,036 \\
\hline Speed of work & 584,83 & 574 & 120,64 & $-0,10$ & 0,16 & 256 & 872 & 0,06 & 0,200 \\
Number of mistakes & 0,09 & 0 & 0,30 & 2,86 & 6,40 & 0 & 1 & 0,53 & $<0,001$ \\
Number of misses & 9,57 & 7 & 8,88 & 2,32 & 6,56 & 0 & 46 & 0,20 & $<0,001$ \\
\hline Self-efficacy & 36,15 & 37 & 4,60 & $-1,43$ & 4,37 & 17 & 44 & 0,15 & 0,005 \\
Perceived strength & 17,56 & 18 & 3,28 & $-0,33$ & $-0,78$ & 11 & 24 & 0,15 & 0,003 \\
Resilience & 18,31 & 18 & 2,87 & 0,12 & $-0,48$ & 12 & 24 & 0,10 & 0,181 \\
\hline $\begin{array}{l}M-\text { mean; } M e-\text { median; } S D-\text { standard deviation; Sk. - skewness; Kurt. - kurtosis; Min i } \text { Maks. - lowest } \\
\text { and highest value; } K-S \text { - Kołmogorow-Smirnow's test result; } p \text { - probability. }\end{array}$
\end{tabular}

The Pearson's $r$ correlation illustrates that in the monolingual group, resilience correlated positively with the speed of work. Moreover, there appears one negative correlation between self-efficacy and a number of mistakes at a statistical tendency level, which might prove the interdependence between a number of mistakes and a level of self-efficacy: the less mistakes, the higher self-efficacy. 
Table 2. Statistical ratio (self-efficacy, verbal fluency level, speed of work and attention for adolescents from monolingual class)

\begin{tabular}{lllll}
\hline & & Self-efficacy & $\begin{array}{l}\text { perceived } \\
\text { strength }\end{array}$ & resilience \\
\hline \multirow{2}{*}{ P - points } & Pearson's $r$ & 0,223 & 0,245 & 0,006 \\
& probability & 0,284 & 0,237 & 0,977 \\
\multirow{2}{*}{ Animals - points } & Pearson's $r$ & $-0,112$ & $-0,151$ & $-0,013$ \\
& probability & 0,595 & 0,471 & 0,951 \\
SUM & Pearson's $r$ & 0,079 & 0,071 & $-0,004$ \\
& probability & 0,707 & 0,735 & 0,986 \\
\hline \multirow{2}{*}{ Speed of work } & Pearson's $r$ & 0,055 & $-0,200$ & 0,567 \\
\multirow{3}{*}{ Number of mistakes } & probability & 0,793 & 0,337 & 0,003 \\
& Pearson's $r$ & $-0,361$ & $-0,296$ & 0,006 \\
\multirow{2}{*}{ Number of misses } & probability & 0,076 & 0,150 & 0,978 \\
& Pearson's $r$ & 0,080 & 0,025 & 0,095 \\
& probability & 0,704 & 0,905 & 0,652 \\
\hline
\end{tabular}

\section{Discussion}

\subsection{Strengths and limitations}

Bilingualism has been a focus of numerous investigations, including various theories and constructs that define this notion. For conducting this study, a person's ability to freely communicate in the second language is viewed as bilingualism. Due to the fact that modern elaborations have proved considerably a strong connection between being bilingual and semantic memory and attention functioning among adults, my attempt was to examine a similar dependence among adolescents. Moreover, these factors were also analysed regarding self-efficacy due to its strong cognitive component thinking.

The aim of the study was to study the connection between cognitive functioning of bilingual and monolingual adolescents and its' relation (or lack of thereof) with self-reported self-efficacy. The results showed some two connections in relation to self-efficacy and resilience. The investigation proved the fact that among monolingual adolescents resilience correlated positively with the speed of work and negatively with the number of mistakes. These findings confirm the assumptions made initially on the interdependency between the perceived level of self-efficacy and the participants' resilience. In spite of the hypotheses being not confirmed, variables correlated significantly. 
In addition, this study's results did not reflect the findings documented in the special literature regarding the bilingual memory and attention. There are possible reasons for not replicating the results in this case: a sample size, tools applied, participants' age and variables not taken under consideration, might have affected the research outcomes.

Most of all, the lack of expected differences might be caused by the insufficient number of participants in both groups in question. Once the study was replicated within a bigger sample, the results might have shown more statistical significance. Given that certain cognitive processes are developed after adolescence, including adult groups into the research would prove efficient.

\section{Conclusions and avenues for further research}

The tools were selected in terms of time for completing the tasks and their simple format in order to maximise the participants' engagement. In terms of further research, I would recommend to evaluate whether completing a more time-consuming task would change their ability to focus.

Another factor to be taken into account is an evident multilingualism among adolescents; it is possible that knowledge of more than two languages might affect the study results. However, evaluating certain functions appears more challenging, since a number of variables have to be considered: the third language itself, a possibility of more than three languages, the level of speakers' expertise. However, this study did not describe adolescents, raised in multicultural families, and, therefore, speak two native languages. It is worth observing these participants' performance, and discuss discrepancies between them and those native speakers, though basically non-native because they have not learnt the language during the critical period. A considerable research focus remains the possibility that bilingual children might experience various educational problems during early stages of primary school education. Hence, it seems rational to conduct a study on how these children would perform as adolescents.

The study was conducted among Polish students of the high school, which causes doubt as to whether it would be possible to extrapolate this research onto a bigger scale. A small sample in this case would certainly not allow for generalisation of results. Due to the insufficient elaboration of performance from the gender studies perspective, which might put forward valuable insights. 
Future research should focus on creating a bigger, more diverse sampling, which would allow for generalizing the results. The study should be conducted in the standardized environment, free from distractions. In order to enhance the sample representativeness, a greater emphasis could be put on the its collection process. Another important factor lies in selecting the appropriate tools range to tackle these processes more efficiently.

\section{References}

Majewicz, A. F. (1989). Języki świata i ich klasyfikowanie. Warszawa.

Bandura, A. (1997). Self-Efficacy. The Exercise of Control. W. H. Freeman \& Co.

Bandura, A. (1997). Self-efficacy: Toward a unifying theory of behavioural change. Psychological Review, 84(2), 191-215.

Bhatia, T. K. (2004). The handbook of bilingualism. Malden, MA: Blackwell.

Chomsky N. (1965). Aspects of the Theory of Syntax, Cambridge \& Massachusetts: The Massachusetts Institute of Technology. T3. pol. (1982) Zagadnienia teorii składni, przeł. I. Jakubczak, Wrocław: Zakład Narodowy im. Ossolińskich.

Collins, A.M. \& Quillian M.R. (1972). Experiments on semantic memory and language comprehension. In: L.W. Gregg (Ed.). Cognition in Learning and Memory (pp.117-147). New York: Wiley.

Collins, J.L. (1982 March). Self-efficacy and ability in achievement behaviour. Paper presented at the annual meeting of the American Educational Research Association, Nowy Jork.

Crystal, D. (1997). English as a Global Language. Cambridge, UK: Cambridge University Press.

Edwards, D. (1997). Discourse and Cognition. London: Sage.

Fishman, J.A. (1968). Sociolinguistic perspective on the study of bilingualism. An Interdisciplinary Journal of the Language Sciences, 6, 21-49.

Juczyński, Z. (1999). Narzędzia pomiaru w psychologii zdrowia. Przegląd psychologiczny, 4, 43-56.

LaBerge, D. (1975). Acquisition of automatic processing of perceptual learning. In P. M. A. Rabbitt \& S. Dornic (Eds.), Attention \& Performance V (pp 50-64). New York: Academic Press.

Maruszewski, T. (2001). Psychologia poznania, Gdańsk: Gdańskie Wydawnictwo Psychologiczne.

Myers-Scotton, C. (2013). Multiple Voices: An Introduction to Bilingualism. Malden, MA: Blackwell.

Nęcka, E., Orzechowski, J., Szymura, B. (2006). Psychologia poznawcza. Sopot: Wydawnictwo Naukowe PWN.

Posner, M. I., \& Snyder, C. R. R. (1975). Attention and Cognitive Control. In R. L. Solso (Ed.), Information Processing and Cognition. Hillsdale, NJ: Erlbaum. 
Prussia, G.E., Klinicki, A.J. (1996). A motivational investigation of group effectiveness using social-cognitive theory. Journal of Applied Psychology, 81, 187-198.

Szepietowska, E.M., Gawda B. (2011). Ścieżkami fluencji werbalnej. Lublin: Wyd. UMCS

Tafarodi, R.W., Swan, W.B. (2001). Two-dimensional self-esteem: Theory and measurement. Personality and Individual Differences, 31, 653-674.

Tulving, E. (1972). Episodic and semantic memory. In E. Tulving, W. Donaldson (Eds.) Organization of memory (pp. 381-403). New York: Academic Press.

Żurek, A.B. (2006). Model kompetencji językowej Noama Chomsky'ego. Rozprawy komisji językowej XXXIII. Wrocławskie Towarzystwo Naukowe. 